\title{
Analysis on the Development of New Energy Automobiles in China Using Multi-Attribute Attitude Model
}

\author{
Huiyuan Han ${ }^{1}$, Xiaomin Gu' ${ }^{2 *}$, Ye Chen ${ }^{1}$ \\ ${ }^{1}$ The Glorious Sun School of Business and Management, Donghua University, Shanghai, China \\ ${ }^{2}$ School of Financial Technology, Shanghai Lixin University of Accounting and Finance, Shanghai, China \\ Email: *huiyuanh@126.com
}

How to cite this paper: Han, H.Y., Gu, X.M. and Chen, Y. (2019) Analysis on the Development of New Energy Automobiles in China Using Multi-Attribute Attitude Model. Modern Economy, 10, 2393-2404. https://doi.org/10.4236/me.2019.1012151

Received: November 7, 2019

Accepted: December 24, 2019

Published: December 27, 2019

Copyright $\odot 2019$ by author(s) and Scientific Research Publishing Inc. This work is licensed under the Creative Commons Attribution International License (CC BY 4.0).

http://creativecommons.org/licenses/by/4.0/

\section{c) (i) Open Access}

\begin{abstract}
The development of new energy automobiles has become the consensus of all countries in the world. With China's oil dependence on foreign countries gradually entering the warning line, the oil consumption of the automobile industry has reached more than $1 / 3$ of the total consumption. So, developing new energy automobiles is an important measure to alleviate the national oil shortage and reduce the dependence on foreign oil. Using the multi-attribute attitude model of consumer behavior, this paper compares the new energy automobiles with the traditional vehicles, and constructs a comprehensive evaluation model of consumers' attitude towards automobile consumption. The research shows that: in cities with high economic development level, consumers' preference for vehicle license plate will promote their choice to buy new energy automobiles; and in cities with general economic development, consumers' preference for new energy automobiles is mainly because of a lower price. Based on this, we then put forward some countermeasures and suggestions, such as innovating the marketing mode of new energy automobile development, improving the core technology of new energy automobile and government investment.
\end{abstract}

\section{Keywords}

New Energy Automobiles, Multi-Attribute Attitude Model, R\&D Innovation

\section{Research Background}

At present, China is stepping into the new normal of economy. As a big country of automobile industry, with the gradual slowdown of automobile production 
and sales in recent years, China's automobile industry is also facing transformation and upgrading. Energy saving and new energy automobile project has been one of the top ten key development areas of "made in China 2025", and the national energy saving policies and regulations are inclined to new energy automobiles. With the continuous development of social technology and the enhancement of people's awareness of environmental protection, new energy automobiles characterized by energy conservation and environmental protection gradually enter the public's vision. No matter the government departments, automobile manufacturers or relevant academic departments, they are all very supportive of the sales and use of new energy automobiles, but the market situation is not up to expectations. In the critical period of China's economic transformation, how to break through the development barriers of market promotion and realize "Innovation driven development strategy" has become a major problem for the development of new energy automobiles. In recent years, with the further development of society, the new energy automobile industry has gradually attracted the attention of researchers, and more and more related research results appear. However, most of the researches concern national policies and corresponding technology innovation, with relatively little attention paid to the consumer market. Consumers are the main body of the market, and their attitudes and tendencies affect the development direction and the trend of the new energy automobile market. Therefore, from the perspective of consumers, it is of great significance for the future development of new energy automobiles to explore the factors that affect consumers' purchasing decisions.

\section{Literature Review}

The multi-attribute attitude model originated from the field of consumer behavior, which was proposed by Fishbein in 1963, also known as the Fishbein model. This model originated in the United States and has been used to explain the purchase behavior of a wide range of products. The model shows that human's explicit behavior cannot be separated from individual intention, which is directly driven by consumer emotion (attitude). Without emotion, there will be no consumption behavior. In recent years, this model has been used in the research of consumption behavior in various fields. Jasuli uses the multi-attribute attitude model to study the students' attitude towards e-learning, and determines the leading attribute of students' use of online learning, and obtains the result of students' attitude towards online learning is positive [1]. Chong \& Yukyeong uses Fishbein model to measure the attitude of coffee companies to VMD, investigate the relationship between consumers' attitude to brand and purchase intention, and make suggestions for the company's marketing strategy [2]. Chen Guoqiang uses the multi-attribute attitude model to calculate the attitude of College Students' Sunshine Physical exercise, which provides reference for improving the overall physical quality of college students [3]. Wassenaar et al. determined 1096 consumers and 310 non consumers' attitudes towards game meat through 
online survey. The results showed that: when deciding to eat game meat, usability, sensory characteristics, ethics of game meat production and health benefits were considered important [4]. Maryani takes Makasa social traditional health center and Kolomadukarangal public health center as examples to analyze consumers' attitudes towards the attributes of scientific herbs [5]. Chen Rongzhang used the multi-attribute attitude model to make a comprehensive evaluation of the consumers' attitude towards the second-hand car dealers [6]. This paper will use multi-attribute attitude model to measure consumers' purchase intention of new energy automobiles.

\section{Development of New Energy Automobile Industry}

\subsection{Overview of New Energy Automobiles}

China's new energy automobiles mainly include three categories: Blade Electric Vehicles (BEV), Hybrid Electric Vehicles (HEV) and Fuel Cell Electric Vehicles (FCEV). Due to immature technology and limited conditions, fuel cell vehicles are not fully promoted in China (Table 1).

According to the development plan for "energy saving and new energy automobile industry (2012-2020)" formulated by the State Council, "by 2020, the production capacity of blade electric vehicles and plug-in hybrid electric vehicles will reach 2 million, and the cumulative production and sales volume will exceed 5 million. The fuel cell vehicles and hydrogen energy industry will develop synchronously with the international industry." At present, blade electric vehicles and plug-in hybrid electric vehicles are comprehensively promoted in cities with more developed economy in China. Through the national and local energy-saving subsidy policies, the purchase cost of new energy automobiles is reduced; and in cities with limited purchase of vehicles, the restriction of purchase of new energy automobiles are liberalized to attract more buyers and promote the sales.

\subsection{Production and Sales of New Energy Automobiles}

With the support of national policies, the production and sales of new energy automobiles are increasing year by year. Since 2005, the production and sales of new energy automobiles in China have shown an obvious upward trend, with an average annual growth rate of more than $30 \%$ [7], indicating a broad prospect in promoting the use of them. From 2013 to 2018, China's new energy automobile industry shows a benign development trend, as shown in Figure 1. However, the new energy automobile market is still in the initial stage of development. Compared with foreign market, there is still a big gap in its development. In 2013 alone, the sales volume of new energy automobiles in the United States reached 96,000 , while Tesla alone sold 18,700, which was more than the total volume of new energy automobiles in China. In 2018, with the rapid development of new energy vehicles, the US automobile market delivered 360,800 vehicles in the whole year, which has reached an $81 \%$ growth rate; among them, Tesla has been 
Table 1. Introduction of three categories of new energy automobiles.

\begin{tabular}{|c|c|c|c|}
\hline Categories & Introduction & Advantages & Disadvantages \\
\hline BEV & $\begin{array}{l}\text { It is a kind of vehicle } \\
\text { which uses a single } \\
\text { battery as the power } \\
\text { source of energy storage. } \\
\text { It uses the battery as the } \\
\text { power source of energy } \\
\text { storage, provides the } \\
\text { electric energy to the } \\
\text { motor through the } \\
\text { battery, drives the motor } \\
\text { to run, thus promotes } \\
\text { the vehicle to run. }\end{array}$ & $\begin{array}{l}\text { The technology is } \\
\text { relatively simple and } \\
\text { mature, and can be } \\
\text { charged wherever there } \\
\text { is power supply. }\end{array}$ & $\begin{array}{l}\text { The energy stored in } \\
\text { the unit weight of } \\
\text { the battery is too } \\
\text { little, and the battery } \\
\text { of the electric vehicle } \\
\text { is more expensive } \\
\text { and has not formed } \\
\text { an economic scale, } \\
\text { so the purchase price } \\
\text { is expensive. }\end{array}$ \\
\hline HEV & $\begin{array}{l}\text { It is a vehicle whose } \\
\text { driving system is } \\
\text { composed of two or more } \\
\text { single driving systems } \\
\text { which can run at the } \\
\text { same time. The driving } \\
\text { power of the vehicle is } \\
\text { provided by a single } \\
\text { driving system or } \\
\text { multiple driving } \\
\text { systems according to } \\
\text { the actual driving state } \\
\text { of the vehicle. }\end{array}$ & $\begin{array}{l}\text { 1) The engine is relatively } \\
\text { small (down size), and it } \\
\text { works under the optimal } \\
\text { condition of low fuel } \\
\text { consumption and less } \\
\text { pollution. } \\
\text { 2) In the downtown area, } \\
\text { the internal combustion } \\
\text { engine can be shut down } \\
\text { and driven by the battery } \\
\text { alone to achieve "zero" } \\
\text { emission. }\end{array}$ & $\begin{array}{l}\text { The system structure } \\
\text { is relatively complex; } \\
\text { the fuel saving effect } \\
\text { of long-distance and } \\
\text { high-speed driving is } \\
\text { not obvious. }\end{array}$ \\
\hline FCEV & $\begin{array}{l}\text { It is a kind of vehicle } \\
\text { driven by the main power } \\
\text { source, which uses the } \\
\text { electric energy generated } \\
\text { by the electrochemical } \\
\text { reaction in the fuel cell } \\
\text { under the action of } \\
\text { hydrogen and oxygen in } \\
\text { the air under the catalyst. } \\
\text { Fuel cell electric vehicle is } \\
\text { essentially a kind of pure } \\
\text { electric vehicles, the main } \\
\text { difference is that the } \\
\text { working principle of } \\
\text { power battery is different. }\end{array}$ & $\begin{array}{l}\text { 1) Zero emission or nearly } \\
\text { zero emission. } \\
\text { 2) Reduce water pollution } \\
\text { caused by oil leakage. } \\
\text { 3) Reduce the emission of } \\
\text { greenhouse gases. } \\
\text { 4) The conversion } \\
\text { efficiency of fuel cell is } \\
\text { high (about } 60 \% \text { ), and the } \\
\text { fuel economy of the whole } \\
\text { vehicle is good. } \\
\text { 5) Stable operation } \\
\text { without noise. }\end{array}$ & $\begin{array}{l}\text { Fuel cells are } \\
\text { expensive, but also } \\
\text { expensive to use } \\
\text { (hydrogen). }\end{array}$ \\
\hline
\end{tabular}

the largest contributor to the growth of the sales since its mass production, and accounting for half of the US electric vehicle market. China still has a long way to go to realize the mission of "overtaking on the curve" in the automobile industry.

\subsection{Current Development Problems of New Energy Automobiles}

As a long-term independent vehicle enterprise with "one leader" in the domestic new energy market, BYD's performance in the first quarter of 2018 surprised the market. Data shows that in the first quarter of 2018, BYD's net profit was 102 


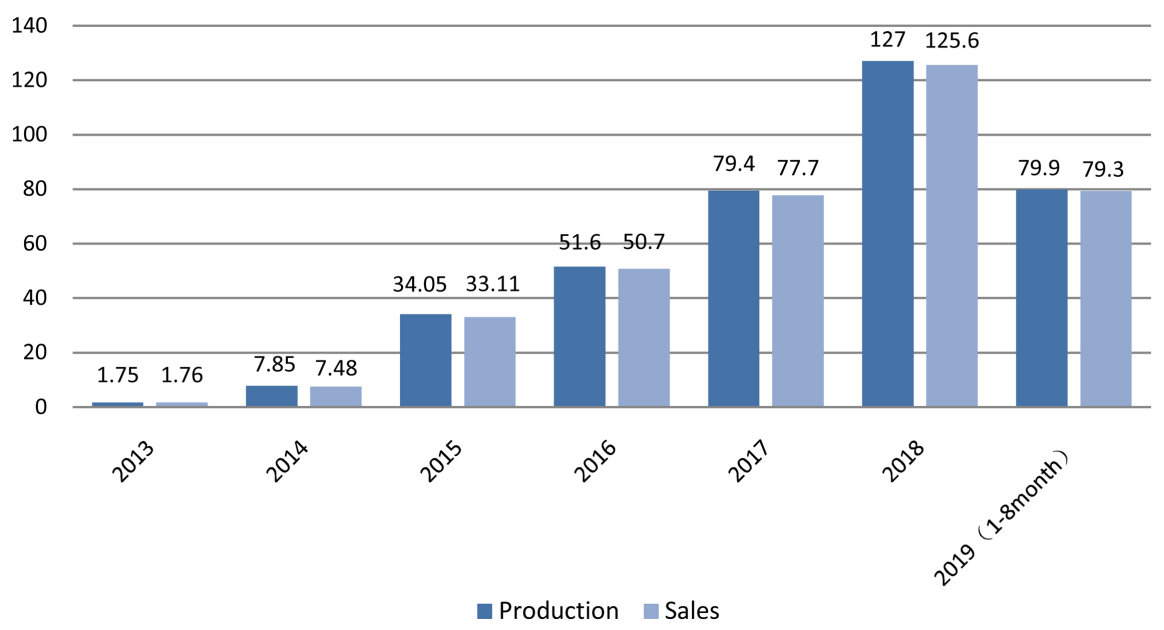

Figure 1. Production and sales of new energy automobiles in China in 2013-2019. Data sources: China Association of Automobile Manufacturers (CAAM) [8]. Note: The above new energy automobiles mainly include Blade Electric Vehicles (BEV), Hybrid Electric Vehicles (HEV) and Fuel Cell Electric Vehicles (FCEV).

million yuan ${ }^{1}$, which is $83.09 \%$ lower than the same period last year. The bigger problem is that the government subsidy received in the first quarter is up to 640 million yuan. If the subsidy is lost, BYD may have a big loss. BYD's market value has been greatly reduced due to poor performance, with the highest decline of nearly 70 billion in the past five months. Not only did BYD fall, but other car companies with new energy automobile business also experienced different degrees of underground sliding. In the first quarter of 2018, the net profit of Yutong Bus dropped $67.4 \%$ year on year, that of Zhongtong bus dropped $97 \%$ year on year, that of Ankai bus dropped $252.39 \%$ year on year, and that of Jianghuai auto dropped $181.7 \%$ year on year ${ }^{2}$.

The main reason for the collective decline of new energy automobile enterprises is the decline of new energy automobile subsidies. According to the "notice on adjusting and improving the financial subsidy policy for the promotion and application of new energy vehicles" issued by the Ministry of finance of the people's Republic of China in February 2018 [9]: From 2018, the subsidy fund for the local purchase of new energy automobiles has been gradually converted into supporting the construction and operation of charging infrastructure, the use and operation of new energy automobiles and other links. In 2018, the subsidy intensity of the new deal will be further reduced. According to the different endurance mileage of automobiles, the number of changes will be different (see Table 2 for details).

It can be seen from the table that the subsidy in 2018 has three changes compared with that in 2017: 1) The subsidy for low endurance mileage models is reduced. 2) The subsidy for models with an endurance of less than $300 \mathrm{~km}$ is reduced. 3) The subsidy for models with an endurance of more than $300 \mathrm{~km}$ is 
Table 2. Comparison of new and old subsidies for new energy automobiles.

\begin{tabular}{ccc}
\hline Endurance Mileage & $\begin{array}{c}\text { Government subsidy } \\
\text { in 2017 }\end{array}$ & Government subsidy in 2018 \\
\hline $100-150 \mathrm{~km}$ & $¥ 20,000$ & 0 \\
$150-200 \mathrm{~km}$ & $¥ 36,000$ & $¥ 15,000$ \\
$200-250 \mathrm{~km}$ & & $¥ 24,000$ \\
$250-300 \mathrm{~km}$ & & $¥ 34,000$ \\
$300-400 \mathrm{~km}$ & & $¥ 44,000$ \\
Over $400 \mathrm{~km}$ & & $¥ 50,000$ \\
Plug in hybrid vehicles $\geq 50 \mathrm{~km}$ & $¥ 24,000$ & $¥ 22,000$ \\
\hline
\end{tabular}

Subsidy amount of single vehicle $=$ mileage subsidy standard $\times$ adjustment coefficient of energy density of battery system $\times$ adjustment coefficient of vehicle energy consumption.

increased. The reduction of government subsidies has led to a sharp decline in the profitability of enterprises, which has also led to a decline in market share. At the same time, the withdrawal of government subsidies makes the problems in the development of new energy automobiles emerge one by one, which is the ultimate reason for the decline of market share.

In addition, China's new energy R\&D started relatively late, the progress is behind the developed countries, and there is a lack of technology. The technical problems are mainly reflected in three aspects: first, the core technology needs to be improved; second, the investment in technology is insufficient; third, the lack of new energy technology talents.

1) Inadequate $R \& D$ in core technology. Taking the power battery technology as an example, compared with Japan, South Korea and the United States, there is a certain gap in the energy density, cycle life, group reliability and thermal management of domestic power batteries. Core technologies such as high specific energy power batteries are still the main bottleneck restricting the development of new energy automobiles in China, and the main products are mostly depend on foreign technology. There is a large industry risk due to the lack of independent and controllable power battery industry chain.

2) Inadequate capital investment. The development of new energy automobile industry requires a lot of basic investment, such as vehicle maintenance network, battery research and charging network. At this stage, the new energy automobile enterprises are far from enough to invest in technology, but simply expand production capacity, and the phenomenon of low-level repeated construction is intensified.

3) Lack of technical talents. As a new technology industry, it has not cultivated talents in many aspects, such as talents needed for key parts of the machine, talents for research and development of new materials, and people to ensure basic knowledge construction.

4) Backward infrastructure. At present, the construction of charging facilities cannot meet the goal of coordinated development of vehicle piles. Since 2016, China's new energy automobile charging infrastructure has made rapid 
development. According to the statistics of China electric vehicle charging infrastructure promotion alliance, the total number of public charging infrastructure (reported by member units of the alliance) in 2017 was 213,900. However, compared with the market demand of new energy automobiles, by the end of 2017, the number of new energy automobiles in China had reached 1.729 million. It can be seen that the current charging infrastructure still has problems such as insufficient number of charging piles, unreasonable layout and inadequate maintenance, which has become the bottleneck of the development of new energy automobile industry.

\section{New Energy Automobile Evaluation Model Construction and Research Design}

So, with the rapid development of new energy automobiles, are consumers' attitudes and purchase intentions affected by their own characteristics or market environment? In the following, we will use the multi-attribute attitude model of consumer behavior to comprehensively evaluate the attitude of automobile consumers based on consumers' experience of traditional automobiles.

\subsection{Variable Setting of the Model}

The model in this paper assumes that the attitude of consumers towards the attitude object (i.e. the new energy automobile discussed in this paper) depends on their evaluation of multiple attributes of the object. The multi-attribute attitude model derives a method to measure the overall attitude of consumers by obtaining specific beliefs and integrating them, which is used to predict the attitude of consumers towards the object. The three variables of the model are:

1) Attributes: are the characteristics of attitude objects. Researchers identify the attributes which most consumers consider when evaluating attitude objects.

2) Beliefs: are the cognition of specific attitude objects (usually related to other attitude objects). Belief measurement is to evaluate the degree to which consumers' perceived objects have certain attributes.

3) Importance weights: reflect the relative importance of an attribute to consumers. Although people think that attitude objects have many attributes, some of them are more important than others, so they are given more weight.

Based on these three factors, we can calculate the overall evaluation of the transaction subject. The formula is as follows:

$$
A_{b}=\sum_{1}^{n} W_{i} X_{i b}
$$

In the formula, $A_{b}$ is the attitude of the consumer towards a certain type of car b. $W_{i}$ gives the weight of attribute " $i$ " to the consumer. $X_{i b}$ is the attribute of the consumer towards brand $b$, and " $n$ " is the number of attributes considered.

\subsection{Research Design}

New energy automobiles are new products, their future development and market 
promotion cannot be separated from the government's policy support, and consumers will also consider the government's policy tendency when purchasing new energy automobiles. Many scholars also pointed out that consumers' green consumption is affected by external intervention factors, among which government policy is a very important factor affecting consumers' green low-carbon consumption behavior. Based on this, this paper uses the method of questionnaire survey to send questionnaires to potential car buyers in different industries and age groups.

1) The design principle of questionnaire

The questionnaire design follows the principles of systematization, scientificity and convenience, and divides the content into four parts: The first part is the attitude of the respondents to the government, the environment and the use of their vehicles. The second part is the attitude and understanding of respondents to new energy automobiles, as well as compared with traditional vehicles. The third part is the factors that influence the respondents to buy new energy automobiles. The fourth part is the basic information of interviewees.

In the investigation of new energy vehicle purchase attitude, Likert scale 7 is used to quantify the attitude of new energy automobiles. These figures only represent the differences in attitude levels. For the convenience of statistics and comparison, they have no absolute difference in value and no significance of fixed value. In terms of investigating consumers' opinions on relevant issues, taking the questions of environmental module as an example, the questionnaire has designed four options: "Environmental issues are closely related to me", "I am worried about global warming", "Renewable energy should be actively explored" and "I know a lot about environmental issues". The respondents are asked to assign values from 1 to 7 , among which, " 1 " represents unimportant, “7” represents very important.

2) Reliability and Validity

In the survey, Shanghai and Wuxi are selected as the representative cities with more developed economy, and Zhengzhou and Kaifeng are selected as the representative cities with less developed economy. A total of 320 questionnaires were distributed to consumers in Shanghai global port business district, Wuxi Vientiane City Business District, Zhengzhou Erqi square business district and Kaifeng Gulou business district, 312 of which were actually recovered, 303 of which were valid and the effective rate was 94.7\%. There were 196 males and 107 females, 72 in Shanghai, 77 in Wuxi, 75 in Zhengzhou and 79 in Kaifeng.

Then we use Excel and spss22.0 to deal with the collected effective data. The Cronbach's alpha is 0.785 , which shows the reliability is within the acceptable range. Kmo value is 0.738 , which is more than 0.5 , Bartlett test result $p$ value is less than 0.05 , the validity of the questionnaire passed the test. There was no significant difference in the score test results of men and women $(P>0.05)$, also no significant difference in the test results of economically developed cities and less developed cities $(\mathrm{P}>0.05)$. And there was no significant difference in the purchase attitude level of new energy automobiles between economically developed 
cities and less developed cities.

\section{Research Results}

\subsection{Determination of Variables of Evaluation Model}

After analysis, we found that when consumers buy new energy automobiles, they mainly consider five factors: price, performance, license plate preference, environmental impact, government participation and after-sales service.

Based on the results of the questionnaire survey, the following assignments are given to attribute " $\boldsymbol{I}$ " of the multi-attribute attitude model and the weight $W_{i}$ assigned to each attribute, as shown in Table 3.

According to statistics, combined with the semantic difference scale, consumers' beliefs about each attribute are shown in Table 4.

\subsection{Evaluation Result}

The result is shown in Table 5. It can be seen that consumers are more satisfied with the price of new energy automobiles, license concessions, environmental protection and government support. For the preferential policies of license plates, in the cities with higher level of economy, take Shanghai as an example, according to statistics, about $75 \%$ of consumers choose to buy new energy automobiles for a Shanghai license plate, while in the cities with general level of economy, people are more sensitive to the price of new energy automobiles. Consumers' evaluation of vehicle performance and after-sales service is not much different from that of traditional vehicles. So although many countries have long realized that new energy automobiles should be used to replace traditional

Table 3. Attributes and weight of consumer evaluation.

\begin{tabular}{cc}
\hline Attributes " $P$ " & $W_{i}$ \\
\hline Vehicle price competitiveness & 3 \\
Vehicle battery performance & 6 \\
License plate acquisition & 5 \\
"Low energy consumption" and "low emission" & 4 \\
Government purchase subsidy, tax preference & 5 \\
After sales service satisfaction & 3 \\
\hline
\end{tabular}

Table 4. Consumer's belief value in automobile.

\begin{tabular}{ccc}
\hline$\dddot{\imath}$ " & $X_{i b}$ & $X_{i b^{*}}$ (Traditional) \\
\hline Vehicle price competitiveness & 5 & 4 \\
Vehicle battery performance & 6 & 5 \\
The difficulty of license plate acquisition & 6 & 2 \\
"Low energy consumption" and "low emission" & 5 & 4 \\
Government purchase subsidy, tax preference & 5 & 4 \\
After sales service satisfaction & 3 & 4
\end{tabular}


Table 5. Evaluation result.

\begin{tabular}{cccccc}
\hline “ & $W_{i}$ & $X_{i b}$ & $A_{b}$ & $X_{i b b^{*}}$ & $A_{b^{*}}$ \\
\hline Vehicle price competitiveness & 3 & 5 & 15 & 4 & 12 \\
Vehicle battery performance & 6 & 6 & 36 & 5 & 30 \\
The difficulty of license plate acquisition & 5 & 6 & 30 & 2 & 10 \\
"Low energy consumption" and "low emission" & 4 & 5 & 20 & 4 & 16 \\
Government purchase subsidy, tax preference & 5 & 5 & $\mathbf{2 5}$ & 3 & $\mathbf{1 5}$ \\
After sales service satisfaction & 3 & 3 & 9 & 4 & 12 \\
Total score & - & - & $\mathbf{1 3 5}$ & - & $\mathbf{9 5}$ \\
\hline
\end{tabular}

vehicles in order to reduce energy consumption and environmental pollution, new energy automobiles are still new things for the majority of consumers, and it is difficult to improve the market share of new energy automobiles. From the perspective of this questionnaire survey, the country started late on new energy automobiles, but consumers' attention and enthusiasm are very high, which is the advantage of developing them. However, due to the lack of consumer awareness of them and their technical doubts, the development of new energy automobiles has great resistance.

\section{Suggestions for New Energy Automobile Enterprises}

From this questionnaire survey, it can be seen that consumers' awareness of environmental protection has been gradually strengthened, their support and expectation for the development of new energy automobiles are higher. Consumers have a higher acceptance of energy-saving and emission reduction of new energy automobiles psychologically. And the development prospect of them is broad. Combined with consumer attitudes and current market conditions, this paper puts forward the following suggestions for new energy automobile enterprises.

\subsection{Innovate the Marketing Mode of New Energy Automobiles}

1) While making efforts to strengthen technology research and development, enterprises should improve the publicity methods of new energy automobiles. In this way, the concept of new energy automobiles can penetrate into consumers' life. In addition to emphasizing the value of energy conservation and environmental protection of new energy automobiles, enterprises should also highlight the safety and quality functions of new energy automobiles, so as to strengthen consumers' awareness and positive attitude towards them.

2) Strengthen and innovate the brand management of new energy automobiles: In the development planning, enterprises should include the establishment of enterprise brand into the strategic deployment, vigorously develop their own brand, accumulate brand reputation, use various ways to increase market publicity, strive to improve brand awareness, and lay a good reputation foundation 
for the development of new energy automobiles.

3) Innovate the combination marketing mode and sales channel, and draw on the successful promotion experience of domestic and foreign automobile enterprises when necessary. New energy automobiles are still new things, so the new and strange marketing methods may bring unexpected effects to the market promotion of new energy automobiles.

\subsection{Improve Core Technology and Capital Investment of New Energy Automobiles}

1) The drive system of new energy automobiles can effectively meet the requirements of power performance. At present, the most important thing to pay attention to is the improvement of power density, dynamic response ability, system efficiency, reliability and other performance of motor and control system. The key technologies include dynamic coupling multi motor drive control, vibration control of complex constraint optimization target system, improvement of motor efficient thermal management technology, and the level of high-temperature automotive electronic materials and equipment.

2) Improving the performance of charging facilities is one of the key points in the development of new energy automobiles. It is necessary to work hard in the aspects of high safety and high power to deal with the consistency of charging interface.

3) A large number of lightweight technologies are used in new energy vehicles, including the application of high-strength steel, magnesium aluminum alloy, high-strength carbon fiber and engineering plastics. Lightweight design and manufacturing technology have also made great progress. This technology will be widely used in the future, and it is worth promoting and researching.

\section{Limitations of Research}

In this paper, we use the multi-attribute attitude model (Fisher bin model) to compare the new energy automobiles with the traditional automobiles, measure the consumers' consumption attitude towards the new energy automobiles, preliminarily analyze the key factors that the buyers in different cities focus on the choice of them, and put forward improvement suggestions for the automobile industry. In future research, we should further overcome the shortcomings of this study.

First of all, this study takes Chinese consumers as samples, and uses two representative cities, Shanghai and Wuxi, in the choice of developed cities. The later research can further expand the coverage of the questionnaire, and the same for the less developed cities. Secondly, in future research, the international comparison of new energy automobile production and sales volume can be further carried out to explore the establishment of international coordination system of new energy automobiles. Thirdly, based on China, under the environment of government intervention in economic system, the universality of some discus- 
sions on bottleneck factors of automobile development needs to be improved. Future research can further study the development differences of new energy interventions under different economic systems.

\section{Conflicts of Interest}

The authors declare no conflicts of interest regarding the publication of this paper.

\section{References}

[1] Jasuli, J. (2018) Analysis of Student Attitudes towards E-Learning Using Fishbein Multiattribute Approach. IOP Conference Series-Materials Science and Engineering, 296, Article No. UNSP 012011. https://doi.org/10.1088/1757-899x/296/1/012011

[2] Chong, Y. (2016) The Effect of the Consumers' Visual Merchandising of Coffee Shops on Brand Attitude and Purchasing Intention: Using the Fishbein's Model of Attitudes. International Journal of Tourism and Hospitality Research, 30, 45-60. https://doi.org/10.21298/ijthr.2016.05.30.5.45

[3] Chen, G. (2013) Multi Attribute Attitude Model and the Measurement and Change of College Students' Attitude towards Sunshine Physical Exercise. Journal of Wuhan Institute of Physical Education, 47, 93-96.

[4] Wassenaar, A., Kempen, E. and van Eeden, T. (2019) Exploring South African Consumers' Attitudes towards Game Meat-Utilizing a Multi-Attribute Attitude Model. International Journal of Consumer Studies, 43, 437-445. https://doi.org/10.1111/ijcs.12523

[5] Maryani, H., Kristiana, L. and Lestari, W. (2017) Fishbein Multiattribute Analysis of Scientific Herbal Medicine (Case Study at Traditional Health Center of Makassar Society and Public Health Center of Colomadu I Karanganyar). Wedia Penelitian Dan Pengembangan Kesehatan, 27, 89-98. https://doi.org/10.22435/mpk.v27i2.5315.89-98

[6] Chen, R. and Ma, Z. (2012) Analysis of Used Car Transaction Subject Based on Multi-Attribute Attitude Model. BAIC, 3, 13-17.

[7] Tang, B. and Liu, J. (2015) Development Prospect of China's New Energy Automobile Industry. Journal of Beijing University of Technology (SOCIAL SCIENCE EDITION), 17, 1-6.

[8] China Association of Automobile Manufacturers (CAAM). Energy Saving and New Energy Automobile Yearbook (2013-2018).

[9] Ministry of Finance of the People's Republic of China (2018) Notice on Adjusting and Improving the Financial Subsidy Policy for the Promotion and Application of New Energy Vehicles, CJ No.18. 